\title{
Konsensus Pakar Anatomi Indonesia mengenai Materi Inti Anatomi Sistem Pencernaan
}

\author{
${ }^{1}$ Siti Munawaroh, ${ }^{2}$ M. Nur D. Kartikasari, ${ }^{3}$ Bulan K. Hermasari \\ ${ }^{1}$ Bagian Anatomi dan Embriologi \\ ${ }^{2}$ Prodi D3 Kebidanan \\ ${ }^{3}$ Unit Pendidikan Kedokteran \\ Fakultas Kedokteran Universitas Sebelas Maret Surakarta \\ Email:munafkuns@gmail.com
}

\begin{abstract}
Anatomy is a basic science which plays an important role in physical examination, confirming diagnosis, and understanding the condition of a patient. Well understanding of anatomy is a great help in any medical practice. Albeit, due to overwhelming anatomical materials, they have to be securely and thoroughly sorted and selected to obtain the effective materials for medical students. This study was aimed to achieve the consensus of anatomy experts about the core anatomical materials of the digestive tract. This was a qualitative study using the Delphi method. Panel, chosen by using purposive sampling, consisted of 20 anatomy lecturers from several medical faculties in Indonesia. The Delphi test was performed in two cycles and the concensus had to obtain $80 \%$. The results showed that the core anatomical material of digestive tract consisted of 117 topics in the first quetionnaire (1st Delphi cycle), and then 9 topics was added and became 126 topics. Of the 126 topics, the experts agreed that there were 87 topics (69\%) that had to be studied by the medical students (2nd Delphi cycle). Conclusion: The Indonesian anatomical experts agreed that there were $69 \%$ of the core anatomical materials of the digestive tract had to be studied by the medical students.
\end{abstract}

Keywords: anatomical material, digestive tract, expert consensus

\begin{abstract}
Abstrak: Anatomi merupakan ilmu dasar yang berguna untuk menjadi landasan bagi dokter dalam melakukan pemeriksaan fisik, diagnosis dan juga memahami kondisi penyakit pasien. Pemahaman anatomi yang baik akan membantu dokter agar bisa berpraktek dengan aman dan efisien. Materi anatomi yang begitu banyak perlu dipilah dan dipilih agar bisa benar-benar efektif untuk dipelajari oleh mahasiswa kedokteran. Penelitian ini bertujuan untuk mendapatkan konsensus dari pakar anatomi di Indonesia mengenai materi inti anatomi sistem pencernaan. Jenis penelitian ialah kualitatif dengan menggunakan metode Delphi. Panel dipilih dengan purposive sampling sejumlah 20 orang dosen anatomi dari berbagai Fakultas Kedokteran di Indonesia. Delphi dilaksanakan dalam dua putaran. Besar konsensus yang ditetapkan ialah $80 \%$. Hasil penelitian memperlihatkan materi inti anatomi sistem pencernaan sejumlah 117 topik pada kuesioner awal (Delphi putaran pertama) menjadi bertambah 9 materi menjadi 126 topik. Dari 126 topik ini para ahli sepakat terdapat 87 topik (69\%) yang harus dipelajari oleh mahasiswa kedokteran (Delphi putaran kedua). Simpulan: Konsensus pakar anatomi Indonesia sepakat bahwa sebanyak 69\% materi inti dari seluruh materi anatomi sistem pencernaan perlu dipelajari oleh mahasiswa pendidikan dokter.
\end{abstract}

Kata kunci: materi anatomi, sistem pencernaan, konsensus pakar

Materi anatomi berperan sangat luas di dalam ilmu kedokteran. Pemeriksaan fisik dasar seperti inspeksi, palpasi, perkusi dan auskultasi, serta pelaksanaan prosedur klinis seperti pengambilan darah arteri dan vena, laparoskopi, anastesi, drainase cairan 
dari rongga tubuh, serta pemahaman terhadap berbagai macam manifestasi trauma merupakan beberapa contoh dari praktek kedokteran yang membutuhkan pemahaman anatomi. ${ }^{1}$ Selain itu, pemahaman anatomi juga sangat bermanfaat untuk menginterpretasikan hasil pencitraan anatomi manusia hidup, seperti foto rontgen, computed tomography (CT) scan dan magnetic resonance imaging (MRI). ${ }^{2}$

Pemahaman anatomi juga diperlukan oleh seorang dokter bedah atau siapa saja yang melakukan tindakan invasif kepada pasien serta saat menjelaskan prosedurnya baik kepada pasien atau keluarga yang bersangkutan. ${ }^{3}$ Terapi invasif minimal dengan teknologi canggih melalui endoskopi terhadap organ dalam tubuh manusia memerlukan pengetahuan anatomi untuk memahami jalan yang ditempuh untuk mencapai target terapi pada tempat yang spesifik. $^{2}$ Sebenarnya masih terdapat perdebatan antara para ahli tentang perlunya dasar pengetahuan anatomi ini dalam melaksanakan tugas-tugas tersebut. Hal ini terjadi karena sebagian ahli berpendapat bahwa tugas-tugas tersebut dapat dilakukan tanpa dasar pengetahuan anatomi melainkan dengan mengikuti protokol dan pedoman yang sudah ada. ${ }^{3}$ Cara ini tidak dapat disebut sebagai pendekatan belajar mendalam ${ }^{4}$ sehingga tidak mampu memberikan bekal yang cukup untuk pengembangan sebagai dokter di masa mendatang. ${ }^{3}$

Kurikulum pendidikan kedokteran banyak mengalami perubahan pada beberapa tahun terakhir. Dahulu desain kurikulum pendidikan kedokteran terbagi menjadi dua tahun pertama berupa materi dasar dan diikuti dua tahun selanjutnya dengan materi klinis. Materi dasar diberikan berbasis disiplin ilmu yang meliputi anatomi, embriologi, neurobiologi, biologi sel/histologi, fisiologi, biokimia, mikrobiologi, farmakologi, dan patologi. ${ }^{5,6}$ Pada kurikulum ini mahasiswa kedokteran terlalu banyak dijejali dengan materi, tetapi kurang dipersiapkan secara adekuat untuk bisa berkomunikasi dengan baik saat berinteraksi dengan pasien. Salah satunya ialah materi anatomi yang dianggap sebagai mata kuliah yang mengalami kegagalan dalam berevolusi dan beradaptasi dengan cepat sehingga mahasiswa yang dididik materi anatomi dengan cara konvensional bisa mempelajari materi secara detail akan tetapi kurang mampu memahami relevansinya dengan praktek klinik. ${ }^{3}$

Selain itu, mahasiswa kedokteran juga akan menjalani rotasi klinik di berbagai bagian yang berbeda di rumah sakit selama masa pendidikan profesi. Tujuannya ialah untuk menjadi dasar pengalaman saat menjalankan tugas sebagai dokter kelak setelah lulus. Pada masa pendidikan ini pemahaman akan materi anatomi sangat diperlukan untuk memahami proses penyakit dan prinsip penanganannya. Jadi, penting bagi mahasiswa kedokteran untuk tidak hanya memahami anatomi tubuh manusia semata melainkan juga memahami bagaimana mengaplikasikan pemahamannya itu ke dalam konteks klinis. ${ }^{7}$ Hal ini dijadikan alasan oleh beberapa sekolah kedokteran untuk melakukan pendekatan belajar dengan problem based learning, self directed learning, dan patient centered learning. Dalam pendekatan belajar yang baru ini terjadi pergeseran dari recall materi menjadi pembelajaran lebih luas yang juga melibatkan keterampilan klinis. ${ }^{8}$ Selain itu juga diterapkan integrasi materimateri yang dipelajari. Integrasi bisa sesama materi dasar yang disebut integrasi horisontal, atau antara materi dasar dengan materi klinis yang disebut integrasi vertikal. $^{5,9}$

Perubahan kurikulum yang terjadi berdampak pada penurunan alokasi waktu yang disediakan untuk pembelajaran anatomi. Hal ini mengharuskan dosen anatomi untuk bisa menjawab pertanyaan ketiga dari sepuluh pertanyaan Harden, yaitu konten apa saja yang harus dimasukkan? Tujuannya ialah mengefektifkan keterbatasan waktu yang tersedia untuk pembelajaran anatomi. Dalam menentukan konten ini terdapat beberapa cara yang bisa digunakan, salah satunya ialah dengan mengadopsi cara identifikasi kebutuhan dalam perencanaan kurikulum oleh Dunn et al. ${ }^{10,11}$ yaitu menggunakan pendekatan 
“orang bijak”, dalam konteks ini yaitu pakar anatomi. Para pakar mendeskripsikan konten apa saja yang menurut mereka dibutuhkan oleh mahasiswa. Mereka dapat menyampaikan pandangannya dalam suatu pertemuan komite, atau secara pribadi menuliskannya dalam bentuk buku, dan dapat pula dengan menggunakan metode Delphi dengan menjadikan mereka sebagai panel dan menyusun konsensus bersama tanpa harus bertatap muka secara langsung. ${ }^{10}$

Dengan melihat latar belakang di atas, maka perlu dipikirkan pengetahuan anatomi minimum apa yang perlu dimiliki oleh seorang calon dokter agar bisa berpraktek dengan aman. Telah terdapat beberapa penelitian mengenai hal ini. Sebagian besar penelitian menggunakan metode Delphi, yang digunakan untuk menyelaraskan proses komunikasi suatu grup sehingga dicapai proses yang efektif guna mendapatkan solusi suatu permasalahan yang kompleks. $^{12}$ Di antaranya ialah penelitian tentang komponen anatomi tulang yang relevan dengan kasus klinis untuk pembelajaran mahasiswa kedokteran, ${ }^{7}$ pengembangan materi inti mengenai anatomi kepala dan leher yang perlu disampaikan untuk mahasiswa kedokteran, ${ }^{13}$ penyusunan core syllabus anatomi untuk mahasiswa kedokteran, terkhusus di bidang neuroanatomi, ${ }^{14}$ serta penelitian core syllabus anatomi untuk semua regio tubuh. ${ }^{15}$

Dari semua penelitian yang telah dilakukan belum ada yang secara khusus membahas mengenai konten materi anatomi sistem pencernaan. Penelitian ini bertujuan untuk mendapatkan konsensus dari pakar anatomi di Indonesia mengenai materi inti anatomi sistem pencernaan yang dibutuhkan oleh seorang calon dokter agar bisa berpraktek dengan aman.

\section{METODE PENELITIAN}

Jenis penelitian ini ialah kualitatif dengan metode Delphi. Metode Delphi merupakan suatu proses komunikasi dalam suatu kelompok yang terdiri dari para ahli di bidang tertentu yang bertujuan mendiskusikan suatu masalah yang spesifik untuk mencapai kesepakatan, menentukan tujuan, menyusun kebijakan atau memrediksi terjadinya peristiwa di masa datang. ${ }^{16}$ Metode ini dilaksanakan dengan menggunakan kuesioner dan dilakukan dalam dua putaran.

Kuesioner awal dibuat oleh peneliti berdasarkan kajian literatur terhadap tiga buku ajar yaitu Gray's Anatomy for Student karya Drake et al, ${ }^{17}$ Clinically Oriented Anatomy karya Moore et al. ${ }^{18}$ dan Sobotta, Atlas of Human Anatomy, Latin Nomenclature. $^{19}$ Hasil kuesioner yang telah disusun kemudian dikonsultasikan kepada pakar anatomi yang berpengalaman yaitu guru besar anatomi, sudah mengajar anatomi kedokteran selama lebih dari 35 tahun, dan sudah memperoleh gelar PAK (Pakar Anatomi Kedokteran) dari PAAI (Perhimpunan Ahli Anatomi Indonesia).

Pada Delphi putaran pertama dibagikan kuesioner kepada panel Delphi. Panel diminta untuk memberi tanda centang pada materi yang penting untuk dipelajari mahasiswa pendidikan dokter. Pada saat pengisian kuesioner putaran pertama ini diharapkan panel Delphi memperhatikan level kompetensi dokter umum yang sudah ditetapkan dalam standar kompetensi dokter Indonesia (SKDI) 2012. ${ }^{20}$ Hasil kuesioner Delphi putaran I dirangkum. Semua materi yang dianggap penting oleh minimal 1 panel Delphi dan juga materi baru yang ditambahkan oleh panel Delphi dimasukkan ke dalam kuesioner baru untuk disebarkan pada Delphi putaran II. Kuesioner ini berisi daftar materi dan pada sisi kanan diberi kolom pilihan 1-4 (not required, acceptable, important, dan essential). Kolom ini menunjukkan tingkat pentingnya dari daftar materi yang ada.

Pada Delphi putaran kedua dibagikan kuesioner kepada panel Delphi. Panel diminta untuk memberi tanda centang pada kolom tingkat pentingnya materi tersebut (1-4) yang dipilih. Pada saat pengisian kuesioner Delphi II, panel diminta untuk tetap memperhatikan level kompetensi dalam standar kompetensi dokter Indonesia (SKDI) 2012.

Hasil Delphi putaran kedua kemudian 
dirangkum untuk dibuat kesimpulan. Level konsensus yang digunakan ialah sebesar 80\%. Artinya, jika ada $80 \%$ responden mengatakan suatu materi sebagai materi penting maka materi tersebut akan masuk sebagai materi inti anatomi sistem pencernaan yang harus dipelajari oleh mahasiswa kedokteran.

Pemilihan subjek penelitian menggunakan purposive sampling berjumlah 20 orang dengan kriteria dosen dengan latar belakang pendidikan dokter dan sudah bergelar S2, telah mengajar dan menguji mata kuliah anatomi mahasiswa pendidikan dokter selama minimal 3 tahun, dan memiliki pengalaman berpraktek sebagai dokter umum minimal 3 tahun.

\section{Etika penelitian}

Ethical clearance dikeluarkan oleh komite etik RSUD Dr. Moewardi dengan No. 162/III/HREC/2016.

\section{HASIL PENELITIAN}

Subjek penelitian (panel Delphi) ini ialah dosen anatomi dari delapan Fakultas Kedokteran di Indonesia. Jumlah panel yang terlibat berjumlah 20 orang. Pada Delphi putaran pertama, dari 20 kuesioner yang disebar terdapat 16 (80\%) yang kembali kepada peneliti sedangkan pada putaran kedua dari 16 kuesioner yang disebarkan, yang kembali kepada peneliti sejumlah 15 kuesioner (93,75\%).

Kuesioner awal yang disusun oleh peneliti dari tiga buku teks didapatkan sejumlah 117 topik anatomi. Pada Delphi putaran pertama terdapat tambahan 9 topik dari panel Delphi, sehingga total topik anatomi pencernaan berjumlah 126 topik. Hasil akhir Delphi putaran kedua mendapatkan sebanyak 87 topik (69\%) yang disepakati oleh pakar anatomi Indonesia sebagai materi inti yang dibutuhkan oleh calon dokter dengan rincian sebagai berikut (Tabel 1).

Tabel 1. Daftar topik sistem pencernaan yang masuk dalam materi inti

\begin{tabular}{|c|c|c|}
\hline No & Topik & $\begin{array}{l}\sum \text { panel memilih sebagai } \\
\text { level } 3 \text { dan } 4(\%) \\
(n=15 \text { orang) }\end{array}$ \\
\hline 1. & Situs visceralis & $13(87)$ \\
\hline 2. & Organ intra peritoneal dan retroperitoneal & $13(87)$ \\
\hline 3. & Duplicatur peritonei & $12(80)$ \\
\hline 4. & Proyeksi organ abdomen pada dinding ventral & $13(87)$ \\
\hline 5. & Proyeksi organ abdomen pada dinding dorsal & $13(87)$ \\
\hline 6. & Annulus inguinalis medialis dan lateralis & $13(87)$ \\
\hline 7. & Dinding abdomen & $14(93)$ \\
\hline 8. & Morfologi cavum oris & $14(93)$ \\
\hline 9. & Struktur/komponen cavum oris & $14(93)$ \\
\hline 10. & Topografi cavum oris & $14(93)$ \\
\hline 11. & Inervasi cavum oris & $12(80)$ \\
\hline 12. & Fungsi cavum oris & $12(80)$ \\
\hline 13. & Morfologi palatum & $14(93)$ \\
\hline 14. & Struktur/komponen palatum & $13(87)$ \\
\hline 15. & Morfologi labia & $13(87)$ \\
\hline 16. & Morfologi dentes & $13(87)$ \\
\hline 17. & Morfologi lingua & $12(80)$ \\
\hline 18. & Struktur/komponen lingua & $13(87)$ \\
\hline 19. & Topografi lingua & $12(80)$ \\
\hline 20. & Vaskularisasi lingua & $12(80)$ \\
\hline 21. & Inervasi lingua & $14(93)$ \\
\hline 22. & Fungsi lingua & $12(80)$ \\
\hline 23. & Morfologi glandula salivares & $14(93)$ \\
\hline 24. & Struktur/komponen glandula salivares & $13(87)$ \\
\hline 25. & Topografi glandula salivares & $14(93)$ \\
\hline 26. & Vaskularisasi glandula salivares & $12(80)$ \\
\hline
\end{tabular}


27. Inervasi glandula salivares

28. Fungsi glandula salivares

29. Morfologi oesophagus

30. Struktur/komponen oesophagus

$15(100)$

31. Topografi oesophagus

32. Vaskularisasi oesophagus

$12(80)$

33. Inervasi oesophagus

$12(80)$

34. Fungsi oesophagus

$13(87)$

35. Morfologi gaster

$15(100)$

36. Struktur/komponen gaster

15 (100)

37. Topografi gaster

$14(93)$

$13(87)$

$13(87)$

39. Inervasi gaster

$13(87)$

40. Fungsi gaster

$15(100)$

Morfologi Intestinum tenue

$15(100)$

$14(93)$

43. Topografi intestinum tenue

13 (87)

$14(93)$

$13(87)$

15 (100)

15 (100)

$14(93)$

13 (87)

$14(93)$

$13(87)$

$15(100)$

$14(93)$

15 (100)

$12(80)$

$14(93)$

15 (100)

$14(93)$

14 (93)

14 (93)

$14(93)$

$13(87)$

$15(100)$

$15(100)$

$15(100)$

15 (100)

13 (87)

$13(87)$

14 (93)

14 (93)

$14(93)$

12 (80)

12 (80)

$13(87)$

$15(100)$

14 (93)

$13(87)$

13 (87)

13 (87)

13 (87)

$15(100)$

13 (87)

15 (100)

14 (93)

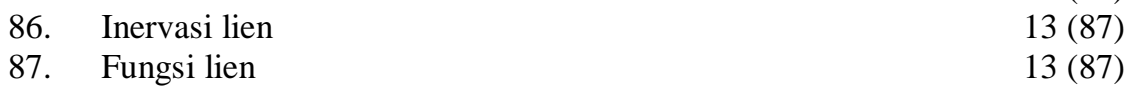




\section{BAHASAN}

Panel Delphi yang digunakan dalam penelitian ini ialah pakar anatomi yang juga memiliki pengalaman dalam berpraktek sebagai dokter umum. Pemilihan ahli anatomi dan klinisi sebagai panel Delphi ini juga diterapkan dalam penelitian Moxham et al. ${ }^{14}$ tentang neuroanatomi dan Tubbs et al. ${ }^{13}$ tentang anatomi kepala dan leher. Alasan dipilihnya pakar anatomi sebagai panel Delphi ialah karena mereka lebih memahami tentang isi materi anatomi itu sendiri dan harus yang memiliki pengalaman berpraktek sebagai dokter umum agar konten yang dipilih sebagai materi yang penting dipelajari oleh mahasiswa pendidikan dokter benar-benar sesuai dengan kebutuhan dokter saat berpraktek kelak setelah lulus. Berbeda dengan penelitian Swamy et al. $^{7}$ yang menggunakan dokter spesialis sebagai panel Delphi dalam penelitiannya dengan alasan dokter spesialislah yang setiap hari berkontak dengan pasien dan juga dokter muda (coas) di rumah sakit, sehingga diharapkan lebih dapat menentukan mana materi anatomi yang benar-benar diperlukan sebagai dasar dalam praktek dokter.

Meskipun anatomi merupakan materi dasar, banyak mahasiswa merasa kesulitan dalam mempelajari anatomi. ${ }^{21}$ Hasil penelitian Anand et al. ${ }^{22}$ di India terhadap 300 mahasiswa mengenai pembelajaran anatomi melaporkan bahwa $60 \%$ mahasiswa menyebutkan anatomi merupakan materi yang sulit untuk dipahami dan tidak mudah berbekas di memori. Beberapa hal yang mungkin menjadi sebab pernyataan ini ialah karena anatomi merupakan materi yang banyak menggunakan istilah asing, yaitu bahasa latin; selain itu juga karena materi anatomi sangat banyak sedangkan waktu yang tersedia untuk pembelajaran anatomi sangat terbatas.

Hasil Delphi putaran kedua mendapatkan sebanyak 87 materi inti dari jumlah total seluruh materi anatomi 126 atau sekitar 69\%. Ini merupakan daftar materi inti yang minimum perlu dipelajari mahasiswa kedokteran agar bisa berpraktek dengan aman sedangkan materi yang tidak dimasukkan dalam materi inti sekitar 39 topik (31\%). Daftar ini diharapkan dapat membantu mengurangi overload materi yang dipelajari mahasiswa. Hal ini dikarenakan perkembangan ilmu pengetahuan dan teknologi telah menjadikan banyak perubahan dalam kurikulum kedokteran.

Salah satu bentuk perubahan yang dialami oleh anatomi ialah pengurangan dalam waktu pembelajaran yang diberikan. $^{23}$ Beberapa hal yang menyebabkan terjadinya pengurangan waktu ini di antaranya ialah pengetahuan biomedis yang diwajibkan untuk mahasiswa preklinik semakin meningkat secara drastis. Selain itu, disiplin ilmu baru seperti hubungan pasien-dokter, bioinformatika, dan lainlain, telah dimasukkan dalam kurikulum tanpa ekstensi yang sesuai dari total waktu yang tersedia. ${ }^{24}$ Dengan keterbatasan waktu ini maka tidak memungkinkan menyampaikan keseluruhan materi anatomi kepada mahasiswa kedokteran sehingga perlu untuk menentukan mana yang harus disampaikan dengan menyesuaikan kompetensi luaran dokter yang diharapkan seperti yang telah dijabarkan SKDI 2012. Hasil penelitian ini bisa dijadikan sebagai salah satu panduan dosen anatomi dalam menyusun materi pembelajaran.

Panel Delphi yang terlibat dalam penelitian berasal dari berbagai Fakultas Kedokteran di Indonesia akan tetapi hasil penelitian ini belum memiliki cukup kekuatan untuk secara resmi merekomendasikannya ke institusi pendidikan dokter di seluruh Indonesia. Oleh karena itu perlu melibatkan PAAI sebagai lembaga yang secara resmi diakui oleh Bagian Anatomi seluruh Fakultas Kedokteran di Indonesia.

\section{SIMPULAN}

Para pakar anatomi Indonesia menyepakati terdapat 87 dari 126 (69\%) materi anatomi sistem pencernaan yang perlu dipelajari oleh mahasiswa pendidikan dokter. Hasil ini merupakan materi inti sebagai pengetahuan minimal yang harus dimiliki seorang calon dokter agar bisa berpraktek dengan efektif dan aman yang telah disesuaikan dengan kebutuhan dokter 
saat berpraktek kelak dan level kompetensi pada SKDI 2012.

\section{Ucapan terima kasih}

Ucapan terima kasih ditujukan kepada Fakultas Kedokteran Universitas Sebelas Maret Surakarta dan Fakultas Kedokteran Universitas Gajah Mada Yogyakarta yang banyak memberikan dukungan dalam proses penelitian ini. Selanjutnya ucapan terima kasih disampaikan kepada Prof. Dr. Didik Gunawan Tamtomo dr., PAK, MM, M.Kes yang telah memberikan banyak masukan dalam penyusunan kuesioner. Penulis juga mengucapkan terima kasih kepada teman sejawat anatomi Indonesia yang bersedia menjadi panel dalam penelitian ini.

\section{DAFTAR PUSTAKA}

1. Educational Affairs Committee, American Association of Clinical Anatomists. A clinical anatomy curriculum for the medical student of the 21st century: gross anatomy. Clin Anat. 1996; 9(2):71-99.

2. McCuskey RS, Carmichael SW. The importance of anatomy in health professions education and the shortage of qualified educators. Acad Med. 2005;80 (4):349-51.

3. Turney BW. Anatomy in a modern medical curriculum. Ann R Coll Surg Engl. 2007;89(2):104-7.

4. Ramsden P. Learning to Teach in Higher Education. London: Taylor \& Francis e-Library, 2002

5. Klement BJ, Paulsen DF, Wineski LE. Anatomy as the backbone of an integrated first year medical curriculum: design and implementation. Anat Sci Educ. 2011;4(3):157-69.

6. Hirt B, Shiozawa T. Clinical anatomy as a modern concept for 21st century teaching, postgraduate education, and research. Kitasato Med J.2013;43:99103.

7. Swamy M, Venkatachalam S, McLachlan J. A Delphi consensus study to identify current clinically most valuable orthopaedic anatomy components for teaching medical students. BMC Med Educ. 2014;14:230.
8. The Education Committee of the Anatomical Society of Great Britain and Ireland. A core syllabus in anatomy for medical students-Adding common sense to need to know. Eur J Anat. 2007;11:3-18.

9. Bergman EM, Vleuten CPMVD, Scherpbier AJJA. Why don't they know enough about anatomy? A narrative review. Medical Teacher. 2011;33:403-9.

10. Harden RM. Ten questions to ask when planning a course or curriculum. Medical education. 1986;20:356365.

11. Harden RM. Curriculum planning and development. In: Dent J, Harden RM, editors. A Practical Guide For Medical Teachers (3rd ed). United States: Churchill Livingstone, 2009; p. 10-6.

12. Linstone HA, Turoff M, editors. The Delphi Method Techniques and Applications. California: Addison Wesley Educational Publisher Inc, 2002.

13. Tubbs R, Sorenson E, Sharma A, Benninger B, Norton N, Loukas $M$, et al. The development of a core syllabus for the teaching of head and neck anatomy to medical students. Clin Anat J. 2014;27(3):321-30.

14. Moxham BJ, Plaisant $O$, Smith CF, Pawlina W, McHanwell S. (2014). An approach toward the development of core syllabuses for the anatomical sciences. Anat Sci Educ. 2014;7(4): 302-11.

15. Smith CF, Finn GM, Stewart J, McHanwell S. Anatomical Society core regional anatomy syllabus for undergraduate medicine: the Delphi process. J Anat. 2016; 228:2-14.

16. Hsu CC, Sandford BA. The Delphi technique: making sense of consensus. PARE. 2007;12(10):1-8.

17. Drake RL, Vogl W, Mitchell AWM. Gray's Anatomy for Students. Singapore: Elsevier, 2007.

18. Moore KL, Dalley AF, Agur AM. Clinically Oriented Anatomy (7th ed.). London: Lippincott Williams \& Wilkins Wolters Kluwer, 2014.

19. Sobotta J. Sobotta, Atlas of Human Anatomy (15th ed.). Paulsen F, Waschke J, editors Munich: Elsevier, 2010.

20. Konsil Kedokteran Indonesia (KKI). Standar Kompetensi Dokter Indonesia (SKDI) (2nd ed.). Jakarta: Konsil Kedokteran Indonesia, 2012. 
8 Jurnal Biomedik (JBM), Volume 10, Nomor 1, Maret 2018, hlm. 1-8

21. Munawaroh S. Penggunaan 4C/ID dan active learning dalam pembelajaran anatomi dalam large group. Jurnal Pendidikan Kedokteran Indonesia. 2015;4(1):7-14.

22. Anand M, Raibagkar C, Ghediya S, Singh P. Anatomy as a subject and career option in view of medical students in India. J Anat Soc India. 2004; 53(1):10-4.
23. Ganguly PK. Teaching and learning of anatomy in the 21st century: direction and the strategy. The Open Medical Education Journal. 2010; 3:5-10.

24. Cho MJ, Hwang YI. Students' perception of anatomy education at a Korean medical college with respect to time and contents. Anat Cell Biol. 2013;46:157-62. 